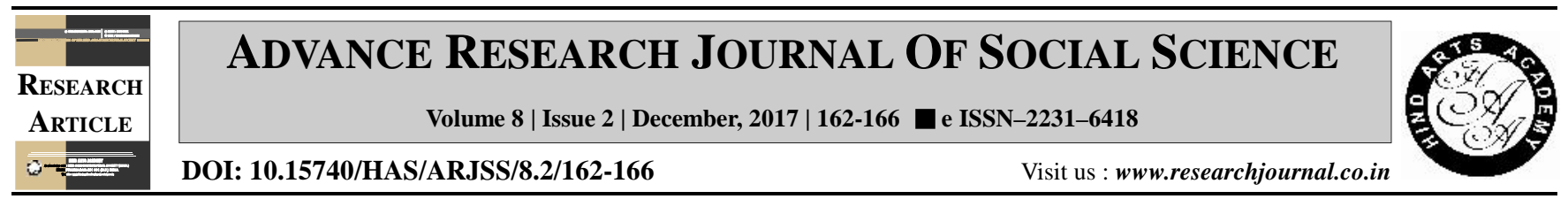

\title{
Effect of intervention programme on psychological abilities of poor children
}

S. Kaushal*, C.K. Singh and R. Malaviya ${ }^{1}$

Department of Human Development and Family Studies, C.C.S. Haryana Agricultural University, HISAR (HARYANA) INDIA ${ }^{1}$ Department of Education, Lady Irwin College, NEW DELHI (INDIA)

(Email: skausha153@gmail.com)

\begin{tabular}{|c|c|}
\hline \multicolumn{2}{|c|}{ ARTICLE INFO : } \\
\hline $\begin{array}{l}\text { Received } \\
\text { Revised } \\
\text { Accepted }\end{array}$ & $\begin{array}{ll}: & 08.06 .2017 \\
: & 21.09 .2017 \\
: & 07.10 .2017\end{array}$ \\
\hline \multicolumn{2}{|c|}{ KEY WORDS : } \\
\hline \multicolumn{2}{|c|}{$\begin{array}{l}\text { Psychological abilities, Cognition, } \\
\text { Intervention }\end{array}$} \\
\hline \multicolumn{2}{|c|}{$\begin{array}{l}\text { HOW TO CITE THIS ARTICLE : } \\
\text { Kaushal, S., Singh, C.K. and Malaviya, } \\
\text { R. (2017). Effect of intervention } \\
\text { programme on psychological abilities of } \\
\text { poor children. Adv. Res. J. Soc. Sci., 8 (2) } \\
: 162-166, \text { DOI: 10.15740/HAS/ARJSS/ } \\
\text { 8.2/162-166. } \\
\text { *Author for correspondence }\end{array}$} \\
\hline
\end{tabular}

\begin{abstract}
This investigation was undertaken to examine psychological abilities of poor children of rural Haryana and to assess effect of intervention programme on psychological abilities of low performer children. To achieve the objectives of the study, 400 children in the age group of 6-8 years belonged to lower income group were selected randomly from Hisar and Ambala districts of Haryana state. McCarthy scales of children's abilities scale developed by McCarthy (1972) was used to measure psychological abilities of the children. Based on pre-testing, intervention programme was developed and implemented on thirty per cent low performer underprivileged children. It was found that deprived children performed poor in verbal, perception, quantitative, memory and motor aspect of cognitive skills. Results revealed that children of Ambala district performed slightly better than children of Hisar district. Further, results shown that there were significant differences in verbal, perception, quantitative, memory, motor and general cognition of experimental group children after execution of intervention programme.
\end{abstract}

